\title{
The relationship and significance of antibody titres as determined by various serological methods in glandular and ocular toxoplasmosis
}

\author{
K. A. KARIM AND G. B. LUDLAM \\ From the Regional Public Health Laboratory, Leeds
}

SYNOPSIS Three types of antibody curve have been demonstrated by testing sera during the cours依 of acquired toxoplasmosis by six different techniques. These three types are due to cell-wall antio body, (demonstrated by four of the techniques), to antibody to soluble antigen, and to $\operatorname{IgM}-$ antibody to the cell wall. These findings have been supported by absorption experiments.

A scheme is presented for testing single sera by two or three different tests to indicate the stage and duration of the infection.

Testing for antibody is normally essential in the diagnosis of toxoplasmosis. The method most commonly used in the past has been the dye test of Sabin and Feldman (1948), or some modification of it (Beverley and Beattie, 1952; Frenkel and Jacobs, 1958). Although specific, sensitive, and reproducible (World Health Organization, 1969), it is technically difficult and slow, requires the use of live parasites and suitable fresh human serum as 'accessory factor'. This has led to a search for less exacting but equally effective techniques. Among these have been various types of complement-fixation test (CFT), (Warren and Russ, 1948; Sabin, 1949; Steen and Kass, 1951; Thalhammer, 1956; Fulton and Fulton, 1965), the indirect haemagglutination test (IHAT), (Jacobs and Lund, 1957), the direct agglutination test (DAT), (Fulton and Turk, 1959; Couzineau and Baufine-Ducrocq, 1970), and the immunofluorescent antibody test (IFAT) for detecting either antitoxoplasma IgG/IgM antibodies (Goldman, 1957; Kelen, Ayllon-Leindl, and Labzoffsky, 1962; Fletcher, 1965) or antitoxoplasma IgM antibody alone (Remington, Miller, and Brownlee, 1968; Dropsy, Carquin, and Croix, 1970). In the work reported here, parallel tests have been carried out by these different techniques with sera from large numbers of patients with suspected glandular or ocular toxoplasmosis. In many patients sera were tested at intervals over many months. Comparisons have been made between the antibody

Received for publication 30 September 1974. titres obtained by the different tests at differen? stages of the infection.

\section{Materials and Methods}

Three hundred and seventy sera from 160 cases of glandular toxoplasmosis and 121 sera from $7 \hbar$ cases of toxoplasma choroidoretinitis were colछ lected over a period of several years and tested by als़. or some of the methods described. Cases of glandulat. toxoplasmosis were selected on a combination of clinical history and raised dye test titre. In many positive cases, the diagnosis was supported by histological evidence. The cases with ocular disease were selected by an initial dye test titre of $1: 64$ of greater together with a supporting clinical diagnosis by an ophthalmologist.

A serum was obtained from each patient togethe with the clinical history and, with each subsequenf specimen, a progress report from the physician-in charge.

\section{SEROLOGICAL TESTS}

Most of the tests described required the initiaf preparation of suspensions of the parasites as free as possible from host cells. Peritoneal exudates from cotton rats inoculated three days previousl ${ }^{0}$ with the RH strain of Toxoplasma gondii were treated in various ways 10 produce purified suspen $\frac{\rho}{8}$ sions of toxoplasma and the final method adopted is described. The exudates were collected in veronalo buffered azide saline (VBS, $0 \cdot 1 \%$ sodium azide) 8 
and the volume from each rat made up to $20 \mathrm{ml}$. Satisfactory washings of the peritoneal cavities containing large numbers of parasites and fewer than $5 \%$ of host cells were pooled, washed twice with the buffer, and the sediment was finally resuspended in $2 \%$ formalin in VBS. After 24 hours' fixation in formalin at $+4^{\circ} \mathrm{C}$, the suspension was centrifuged and the sediments were resuspended in $0.2 \%$ formol-saline. After standing for one hour the suspension was removed from particles that had settled out at that time. Exudates that contained more numerous host cells were squirted repeatedly through a fine needle (gauge 25) to break up clumps and disintegrate cells containing parasites. The suspension was then partially purified by slow centrifugation followed by filtration through sintered glass filters (Baird and Tatlock, porosity 20-30 $\mu \mathrm{m}$ ). Satisfactory suspensions obtained in this way were then treated by formalin as above.

\section{Haemagglutination test}

The test used was a modification of that described by Jacobs and Lunde (1957). The parasites obtained and purified as described above but without formalinization were lysed in distilled water, $1 \mathrm{ml}$ of water being added to every $5 \times 10^{8}$ parasites. After 24 hours at $+4^{\circ} \mathrm{C}$, the suspension was transferred to a Mickle cell, an equal volume of small glass beads (grade 12 ballotini) added and the mixture shaken for 10 minutes on a Mickle disintegrator. The beads were removed by filtration and the filtrate centrifuged at $4000 \mathrm{rpm}$ for 10 minutes. The clear supernatant (soluble antigen) was then stored at $-20^{\circ} \mathrm{C}$ until required. Red blood cells were sensitized with this antigen using a modification of the technique described by Jennis (1966). Varying dilutions of the antigen were added to $2 \%$ suspensions of pyruvic-aldehyde-treated human group 0 , rhesus-negative cells, and the coating was carried out at $56^{\circ} \mathrm{C}$ for one hour in phosphate-buffered saline, $\mathrm{pH} 6 \cdot 0$. The cells were then washed once with PBS (pH 7.2) and resuspended in the same buffer with $0.1 \%$ sodium azide at a final concentration of cells of $1 \%$. The dilution of antigen which gave the the highest titre in the IHAT with a standard positive serum (standardized against the WHO international standard serum) and no agglutination with a negative dye test serum was thus determined. This dilution was used to prepare bulk batches of sensitized cells for use as HA antigen. The use of human erythrocytes instead of sheep cells obviated the need for absorbing sera with unsensitized sheep red cells, to remove heterophile antibody.

The tests were carried out in Microtiter plates, v wells, using $40 \mu \mathrm{l}$ of test serum, diluted in $2 \%$ fetal-calf-serum saline, and $40 \mu \mathrm{l}$ coated red cells.
The plates were read after two and a half hours and the highest dilution of serum giving an irregular rough button of red cells surrounded by a lawn covering the entire bottom of the well was taken as the endpoint.

\section{Complement-fixation test}

Antigen for the CFT was prepared and formalinized from cotton-rats as described above. The optimum dilution of the antigen was determined by the usual chessboard technique and was generally found to be $2-8 \times 10^{6}$ parasites per $\mathrm{ml}$. The test followed the technique described by Bradstreet and Taylor (1962) for virus CFT, but using Microtiter plates, $\mathrm{u}$ wells, and $1 \frac{1}{2} \%$ sensitized sheep red cells and adopting the longer overnight fixation.

\section{Direct agglutination test}

The concentration of the formolized toxoplasma suspension obtained above was adjusted to approximately $7 \times 10^{7}$ per $\mathrm{ml}$. The test sera were diluted in $0.4 \%$ bovine albumin borate saline buffer and serial dilutions made in a Microtitre plate, $v$ wells, $25 \mu \mathrm{l}$ of the antigen being added to $25 \mu \mathrm{l}$ of the serum dilution. The plate was shaken in a Luckham shaker for 15 minutes and left overnight at room temperature before reading the test. Agglutination was shown by a diffuse lawn of parasites or an irregularly shaped button, whilst a clearly defined button represented a negative reaction. The highest dilution of the serum producing disruption of the button, with an irregular periphery, was considered the endpoint.

\section{Methylene blue dye test \\ The dye test technique followed that of Beverley and Beattie (1952) modified from Sabin and Feldman (1948).}

\section{Indirect fluorescent test for toxoplasma antibodies}

The concentration of the toxoplasma suspension formolized as described above was adjusted to approximately $7 \times 10^{6}$ parasites per $\mathrm{ml}$, and multiple spots of the suspension were placed on a glass slide by the method described by Chessum (1970). The smears, parasites distributed evenly without overlaps, were air dried and stored at $-20^{\circ} \mathrm{C}$ until used. Dilutions of sera were made in a Microtiter plate and transferred by a template to the smears on the slides. Other reagents were placed on the smears in a similar manner.

For detecting an antitoxoplasma immunoglobulin mixture of IgG/IgM, fluorescein-conjugated antihuman immunoglobulins (Wellcome Reagents) were used at a dilution usually of $1: 20$. Fluoresceinconjugated antihuman IgM, obtained from Nordic 
Diagnostics (batch no.1 071), was used at a dilution of $1: 20$. After final washing the smears were counterstained with Evans blue (1:5000).

The slides were examined with a Reichert fluorescent microscope with a wide, dark field, immersion condenser, excitation filter UGI/1.5 mm, absorption filter GG13/1 $+3 \mathrm{~mm} \times$ Wrattenfoil $2 \mathrm{~A}, \times 40$ objective and $\times 6.3$ binocular eyepieces.

The titre of the test serum was taken as the highest dilution which produced bright complete peripheral fluorescence in the majority of the parasites in several fields of the smear. Incomplete peripheral, or faint staining or fluorescence of only the tips of the parasites was ignored.

\section{ABSORPTION EXPERIMENTS}

\section{Using whole parasites}

Freshly obtained, washed parasites, both formalinfixed and unformalinized were used to absorb antitoxoplasma sera. The concentration of the parasites was adjusted to $2 \times 10^{8}$ per $\mathrm{ml}$ and $5 \mathrm{ml}$ of the suspension was centrifuged at $3000 \mathrm{rpm}$ for 10 minutes. The pellet was resuspended in a minimum volume of saline and added to serum to give a final dilution of $1: 8$. This was incubated at $37^{\circ} \mathrm{C}$ for 30 minutes and then overnight at $+4^{\circ} \mathrm{C}$. The parasites were then centrifuged out and the serum was tested by the various methods describe above. Control tests were carried out on serum diluted in saline without the antigen.

\section{Using $H A$ antigen}

Serum dilutions, $1: 4$ or $1: 8$, were made in a $12 \%$ suspension of sensitized cells and similar dilutions in $12 \%$ unsensitized cells as controls. The reaction mixture was incubated at $37^{\circ} \mathrm{C}$ for 30 minutes and then overnight at $+4^{\circ} \mathrm{C}$. The supernatant serum was then collected and examined by the various tests.

\section{Results}

The results of the tests from patients with toxoplasma lymphadenopathy are shown in fig 1 and tables I and III, and from patients with ocular toxoplasmosis in table II.

For each test the results were grouped within the periods of time, shown in table I, from the onset of disease as given by the clinician. These were 0 to one month, one to three months, and so on. Within each period of time the geometric-mean titre, and $95 \%$ confidence interval has been calculated.

Table III shows the results for glandular toxoplasmosis of one and a half to three years' duration,

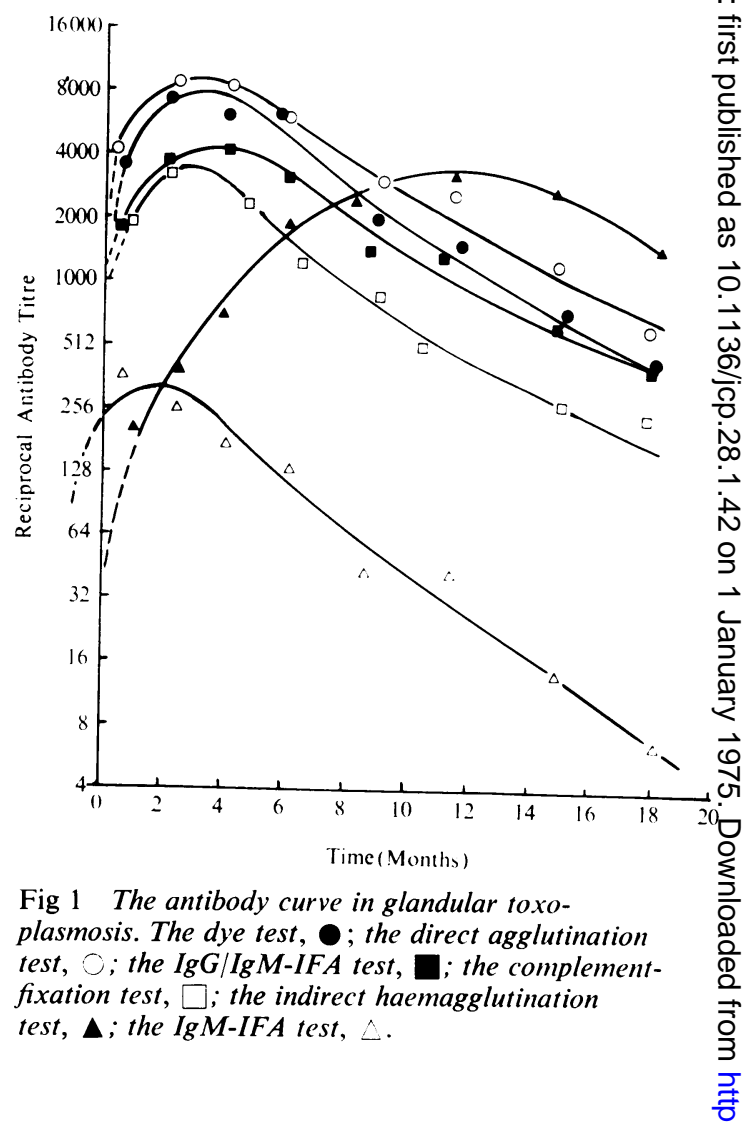

the mean titre for each test, the range and the $95^{\circ}$ confidence interval.

Tables I, II, and III show the wide range of titres at all stages of the disease. The titre curves of the antibodies (fig 1) in glandular toxoplasmosis when measured by the various tests show that the IgM levels reach their peak first, at one or two months? whereas the titres measured by the dye complement fixation, direct agglutination, and IgG/IgM-immuno근. fluorescent antibody tests run parallel with one another, all reaching their peaks about two to six months. The titres in the indirect haemagglutination test rise more slowly to reach a maximum in the period of six to 14 months. With the IgM test, there is a fall in antibody titre to become eventuallye less than $1: 8$ at any time after 18 months, but with the other tests there is a much slower fall and the results remain positive at higher levels indefinitely $\frac{T}{0}$ The results of glandular toxoplasmosis one and ac half to three years after onset show that the indirect haemagglutination titre is greater than that of the dye test with a low or negative IgM titre, a patterne resembling the results for ocular disease (table II) $ᄋ$ Tables IV and V show the titres of antitoxo 


\begin{tabular}{|c|c|c|c|c|c|c|c|c|}
\hline \multirow[t]{2}{*}{ Test } & \multicolumn{8}{|c|}{ Duration (Months) ${ }^{1}$} \\
\hline & $0-1$ & $1-3$ & $3-5$ & $5-7$ & $7-10$ & $10-13$ & $13-17$ & $17-21$ \\
\hline $\begin{array}{l}\text { Dye (a) } \\
\text { (b) }\end{array}$ & $\begin{array}{l}2951 \\
1710-5120\end{array}$ & $\begin{array}{l}7278 \\
5430-9730\end{array}$ & $\begin{array}{l}5508 \\
4150-7345\end{array}$ & $\begin{array}{l}5117 \\
3850-6790\end{array}$ & $\begin{array}{l}1980 \\
1285-2570\end{array}$ & $\begin{array}{l}1380 \\
1130-2390\end{array}$ & $\begin{array}{l}590 \\
464-798\end{array}$ & $\begin{array}{l}388 \\
77-1950\end{array}$ \\
\hline Indirect haemagglutination & $\begin{array}{l}2200 \\
174-355\end{array}$ & $\begin{array}{l}375 \\
332-600\end{array}$ & $\begin{array}{l}640 \\
470-900\end{array}$ & $\begin{array}{l}1920 \\
1200-3055\end{array}$ & $\begin{array}{l}2500 \\
1800-3240\end{array}$ & $\begin{array}{l}3240 \\
1510-7000\end{array}$ & $\begin{array}{l}2760 \\
1320-5740\end{array}$ & $\begin{array}{l}1450 \\
410-5140\end{array}$ \\
\hline Complement-fixation & $\begin{array}{l}2290 \\
1183-2570\end{array}$ & $\begin{array}{l}3236 \\
3083-3396\end{array}$ & $\begin{array}{l}2270 \\
1521-3396\end{array}$ & $\begin{array}{l}1270 \\
190-2190\end{array}$ & $\begin{array}{l}798 \\
571-1096\end{array}$ & $\begin{array}{l}434 \\
178-1052\end{array}$ & $\begin{array}{l}496 \\
50-1520\end{array}$ & $\begin{array}{l}210 \\
117-326\end{array}$ \\
\hline Direct agglutination & $\begin{array}{l}4040 \\
2370-6880\end{array}$ & $\begin{array}{l}8970 \\
8790-9290\end{array}$ & $\begin{array}{l}7690 \\
5957-9795\end{array}$ & $\begin{array}{l}6295 \\
4831-8185\end{array}$ & $\begin{array}{l}2950 \\
2061-4178\end{array}$ & $\begin{array}{l}2740 \\
1563-4477\end{array}$ & $\begin{array}{l}3160 \\
380-3490\end{array}$ & $\begin{array}{l}616 \\
299-1276\end{array}$ \\
\hline $\begin{array}{l}\text { IgG/IgM-indirect } \\
\text { fluorescent Antibody }\end{array}$ & $\begin{array}{l}1884 \\
1306-2720\end{array}$ & $\begin{array}{l}4325 \\
3610-5188\end{array}$ & $\begin{array}{l}3126 \\
2570-3802\end{array}$ & $\begin{array}{l}3100 \\
2523-3819\end{array}$ & $\begin{array}{l}1320 \\
963-1820\end{array}$ & $\begin{array}{l}1350 \\
1242-1493\end{array}$ & $\begin{array}{l}612 \\
362-1038\end{array}$ & $\begin{array}{l}369 \\
198-690\end{array}$ \\
\hline $\begin{array}{l}\text { IgM indirect fluorescent } \\
\text { antibody }\end{array}$ & $\begin{array}{l}370 \\
218-627\end{array}$ & $\begin{array}{l}275 \\
210-357\end{array}$ & $\begin{array}{l}175 \\
134-230\end{array}$ & $\begin{array}{l}128 \\
95-170\end{array}$ & $\begin{array}{l}42 \\
30-50\end{array}$ & $\begin{array}{l}39 \\
28-56\end{array}$ & $\stackrel{14}{9-21}$ & $\begin{array}{l}7 \\
4-12\end{array}$ \\
\hline
\end{tabular}

Table I Antibody titres at periods after onset of clinical disease in patients suffering from glandular toxoplasmosis

(a) Geometric mean antibody titre

(b) $95 \%$ confidence interval

${ }^{1}$ Durations falling on the boundary between two groups, eg, one month, three months etc, have been divided equally between the two groups.

\begin{tabular}{llcl}
\hline Test & No. of Specimens & Mean Titre & Range \\
\hline Dye & 120 & 294 & $64-4000$ \\
Indirect haemagglutination & 121 & 1091 & $64-32000$ \\
Complement-fixation & 105 & 139 & $16-4000$ \\
Direct agglutination & 110 & 500 & $32-8000$ \\
IgG/IgM indirect fluorescent & 118 & 280 & $64-4000$ \\
IgM indirect fluorescent & 117 & $5 \cdot 5$ & $<8-64$ \\
\hline
\end{tabular}

Table II Antibody titres of patients with ocular toxoplasmosis

\begin{tabular}{llccc}
\hline Test & No. of Specimens & Mean Titre & Range & 95\% Confidence Interval \\
\hline Dye & 80 & 252 & $64-4000$ \\
Indirect haemagglutination & 78 & 2477 & $512-32000$ \\
Complement-fixation & 73 & 104 & $32-2000$ & $1980-3133$ \\
Direct agglutination & 54 & 250 & $32-4000$ & $100-200$ \\
IgG/IgM indirect fluorescent & 75 & 251 & $64-4000$ & $2194-328$ \\
IgM indirect fluorescent & 77 & 3 & $3-300$ \\
\hline
\end{tabular}

Table III Antibody titres one and a half to three years after the onset of glandular toxoplasmosis

\begin{tabular}{|c|c|c|c|c|c|c|c|c|c|c|}
\hline \multirow[t]{3}{*}{ Serum } & \multicolumn{10}{|l|}{ Test } \\
\hline & \multicolumn{4}{|c|}{ Indirect Haemagglutination Dye } & \multicolumn{2}{|c|}{ Complement-fixation } & \multicolumn{2}{|c|}{$\begin{array}{l}\text { IgG/IgM Indirect } \\
\text { Fluoresecent Antibody }\end{array}$} & \multicolumn{2}{|c|}{$\begin{array}{l}\text { IgM-immunofuorescence } \\
\text { Antibody }\end{array}$} \\
\hline & Unabsorbed & Absorbed & Unabsorbed & Absorbed & Unabsorbed & Absorbed & Unabsorbed & Absorbed & Unabsorbed & Absorbed \\
\hline $\begin{array}{l}1 \\
2 \\
3 \\
4 \\
5\end{array}$ & $\begin{array}{c}32000 \\
512 \\
512 \\
256 \\
2048\end{array}$ & $\begin{array}{r}16000 \\
512 \\
256 \\
256 \\
4096\end{array}$ & $\begin{array}{r}32000 \\
1024 \\
512 \\
1024 \\
8192\end{array}$ & $\begin{array}{r}512 \\
64 \\
32 \\
<32 \\
64\end{array}$ & $\begin{array}{r}16000 \\
512 \\
256 \\
512 \\
4096\end{array}$ & $\begin{array}{r}128 \\
64 \\
32 \\
32 \\
16\end{array}$ & $\begin{array}{c}16000 \\
2048 \\
1024 \\
1024 \\
4096\end{array}$ & $\begin{array}{r}128 \\
32 \\
16 \\
32 \\
32\end{array}$ & $\begin{array}{r}512 \\
64 \\
32 \\
16 \\
128\end{array}$ & $\begin{array}{l}<8 \\
<8 \\
<8 \\
<8 \\
<8\end{array}$ \\
\hline
\end{tabular}

Table IV Serological tests on antitoxoplasma sera absorbed by washed formolized toxoplasma cells 


\begin{tabular}{|c|c|c|c|c|c|c|c|c|c|}
\hline \multirow[t]{3}{*}{ Serum } & \multicolumn{8}{|l|}{ Test } & $\overline{\vec{C}}$ \\
\hline & \multicolumn{2}{|c|}{ Indirect Haemagglutination } & \multicolumn{2}{|l|}{ Dye } & \multicolumn{2}{|c|}{ Complement-fixation } & \multicolumn{2}{|c|}{ IgM-Indirect Fluorescent } & 읃 \\
\hline & Unabsorbed & Absorbed & Unabsorbed & Absorbed & Unabsorbed & Absorbed & Unabsorbed & Absorbed & $\overline{\bar{D}}$ \\
\hline $\begin{array}{l}1 \\
2 \\
3 \\
4\end{array}$ & $\begin{array}{r}32000 \\
256 \\
2048 \\
64\end{array}$ & $\begin{array}{l}16 \\
<8 \\
<8 \\
<8\end{array}$ & $\begin{array}{c}32000 \\
1024 \\
2048 \\
128\end{array}$ & $\begin{array}{c}16000 \\
512 \\
4096 \\
128\end{array}$ & $\begin{array}{c}4096 \\
512 \\
1024 \\
128\end{array}$ & $\begin{array}{c}8192 \\
256 \\
1024 \\
64\end{array}$ & $\begin{array}{c}128 \\
64 \\
16 \\
<8\end{array}$ & $\begin{array}{r}256 \\
64 \\
32 \\
<8\end{array}$ & $\begin{array}{l}\overrightarrow{\mathbb{D}} \\
\frac{\mathrm{Q}}{\infty}\end{array}$ \\
\hline
\end{tabular}

Table V Serological tests on antitoxoplasma sera absorbed by soluble-antigen-sensitized red cells

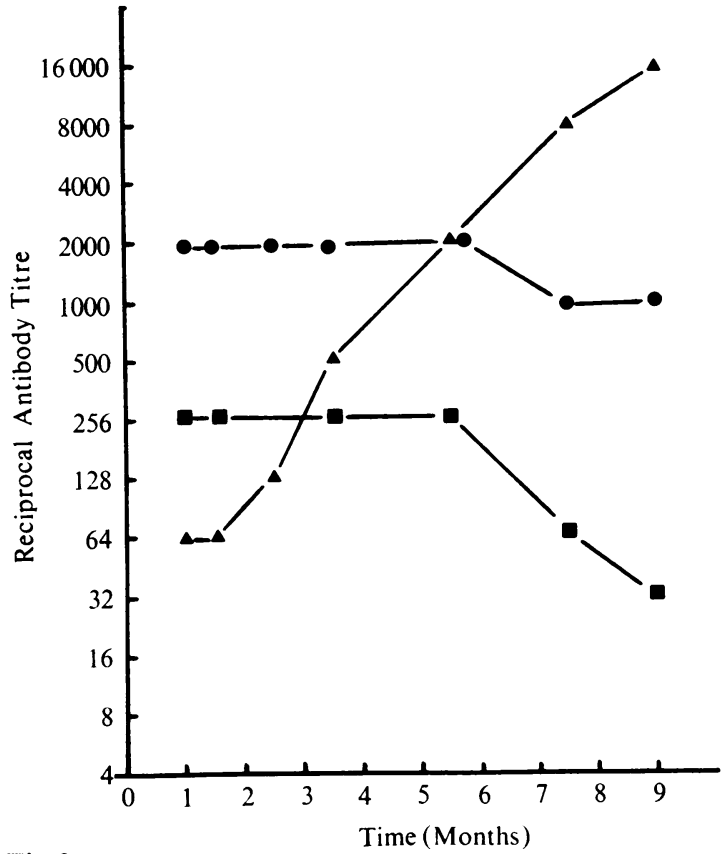

plasma sera before and after absorption with variots antigens. Absorption with whole parasites, eitheft formolized or unfixed, resulted in a removæ of dye test, complement-fixation, IgG/IgM:immunofluorescent and IgM antibodies whilse the HA antibody was unaffected. When sensitize cells were used for absorbing the sera, HA antibody was removed, the dye test, complement-fixation, IgG/IgM-immunofluorescent, and IgM titres maining unchanged.

Figures $2 \mathrm{a}$ and $2 \mathrm{~b}$ show antibody curves from individual cases selected from the series; fig 20 shows representative curves and fig $2 b$ is less typical in that the indirect haemagglutination test curze never rises to a higher level than that of the dy test.

\section{Discussion}

A satisfactory serological diagnosis of toxoplasmosis requires the demonstration of a four-fold or greater change in antibody titre. However, as shown fig 1 , the titres obtained in the majority of tes have already reached high levels by about two months, and high titres may persist for months $\underline{\underline{\theta}}$ r

Fig 2a

Fig 2 Antibody curves in two cases of glandular toxoplasmosis Dye test, ; haemagglutination test, $\Delta$; the IgM-IFA test, a typical relationship b atypical relationship.

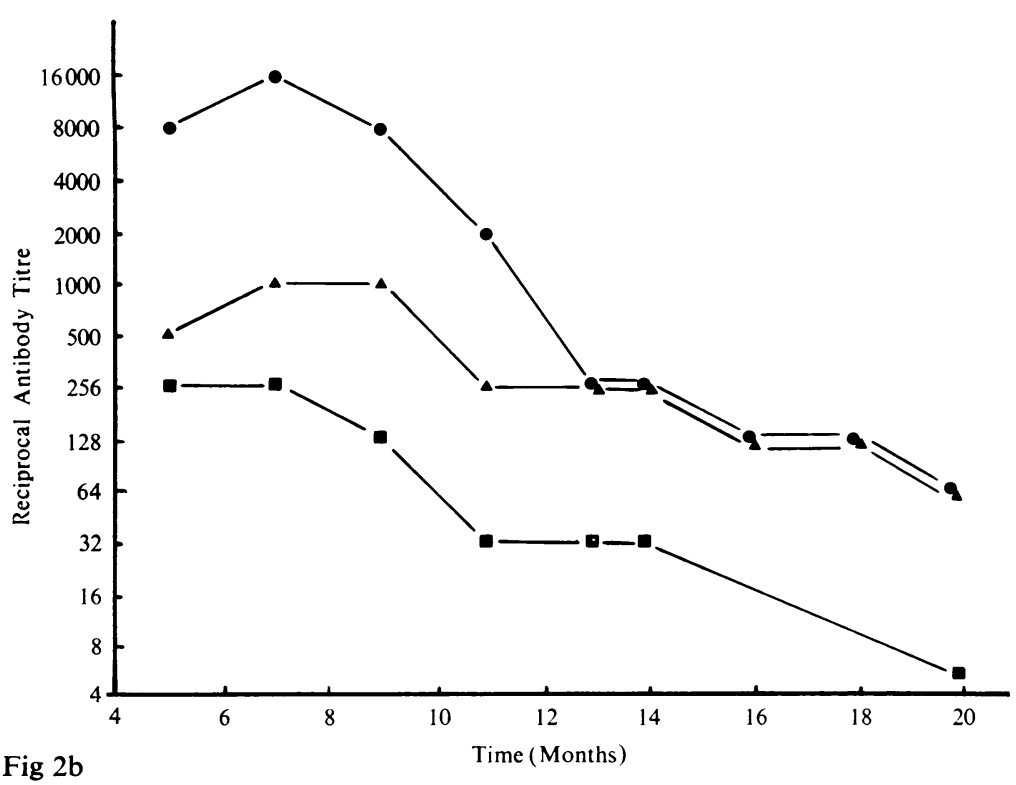


years. As it is unusual to obtain sera before this time, it is often difficult to demonstrate a rise in titre. There is therefore a special need to make the maximum use of a single serum and this can be done by carrying out two or more tests giving different types of information. The frequency with which toxoplasma antibodies are found in the general population, about $30 \%$ in England and the USA (Beattie, 1957; Feldman and Miller, 1956), also creates a need for tests which distinguish between these antibodies and those produced as a result of recent infection. Sabin, for example, as early as 1949 suggested that the complementfixation test (Warren and Russ, 1948) could be a valuable additional test for proof of active infection, since the complement-fixation test (using soluble antigen) reverted to negative with the subsidence of the infection.

The characteristics of the curves in fig 1 suggest three different types of antigen-antibody reaction in the serological methods used in the present series. The indirect haemagglutination curve is distinct from the curves of the complement-fixation, dye test, direct haemagglutination, and IgG/IgMimmunofluorescent antibody tests, all of which run closely parallel and appear to measure the same antibody. The third type of reaction, the IgMimmunofluorescent antibody test, differs from others in that a particular class of antibody (IgM) is involved.

Absorption of high-titre antitoxoplasma sera (table IV) by intact parasites indicates that the surface or cell-wall antigen combines with the antibody reacting in the complement-fixation, direct agglutination, dye, and immunofluorescent antibody tests, but not with HA antibody. Fleck (1961), using a toxoplasma-infected mouse peritoneal exudate, removed complement-fixation and dye test and $\mathrm{HA}$ antibodies. The presence or absence of HA antigen on the intact cell wall of the parasite has important implications in toxoplasma serology as will be discussed later, but the peritoneal exudate in Fleck's experiment may well have contained soluble antigen. Red cells sensitized with such an antigen are capable of absorbing HA antibody (as was shown by Fleck), the dye, complement-fixation, and IgM-immunofluorescent antibody tests being unaffected (table V).

Further evidence for the presence of two antigens came from Lunde and Jacobs (1967). Predominantly indirect haemagglutination test antibodies resulted following immunization of a rabbit with a 40000 rpm supernatant fraction and predominantly dye test antibodies from immunization of a rabbit with toxoplasma 'ghosts' after cell sap had been extracted by lysing the parasites in distilled water. The concept, therefore, of cell-wall antibody and HA antibody corresponding to the two antigens may be used in discussing the toxoplasma antibody response. Several reports comparing the haemagglutination and dye test titres have appeared in the literature, some claiming a close correlation between the two (Jacobs and Lunde, 1957; Knierim, Niedmann, and Thiermann, 1960; Thorburn and Williams, 1972; Tönder, Closs, and Digraves, 1974), others reporting varying degree of discrepancy (Mitchell and Green, 1960; Lewis and Kessel, 1961; Chordi, Walls, and Kagan, 1964). Both groups of workers can justify their conclusions but the reported studies probably reflect the limitations imposed by their choice of material and may at times be misleading. Although two different antibodies are being measured by the tests, a large number of cases fall in the group in which the cellwall antibody runs parallel with and more or less equal to the indirect haemagglutination test, but our work has shown that differences between the two tests occur mainly early in the infection and at a later stage, both periods when sera are less commonly tested.

The third type of antibody, the IgM determined by FAT using whole formalin-fixed parasites as antigen, is one produced against the surface or cell-wall antigen and not the soluble antigen (table V). The titre of this antibody remains raised for a number of months and then gradually falls to become negative in 18 months or less in the majority of cases. Since this antibody persists beyond the period of illness, as was also found by Remington et al (1968) and Thiermann and Stagno (1971), its value is somewhat diminished. Nevertheless, especially used in combination with other tests, it is valuable in that a higher titre, 1:64 or greater, suggests a recent infection and a negative result a past infection, probably one that occurred at least 18 months before (tables I and III).

A low indirect haemagglutination test titre combined with a cell-wall antibody titre at least eightfold higher and a high level of IgM indicates a relatively recent infection, of less than four months' duration (fig 1). Later, at about six to eight months the indirect haemagglutination test titre becomes equal to or greater than the cell-wall antibody titre and at the same time, there is a fall in the IgM antibody. It has been found possible in practice to predict the approximate onset of the disease by comparing the titres obtained in the various tests on a single serum. The antibody curves for individual cases of glandular toxoplasmosis illustrate the validity of the interrelationship and its usefulness, but inevitably in some the antibody curve will not follow the usual course (fig 2b). However, for all 
glandular cases, the HA to cell-wall antibody titre difference early in the disease has been a constant finding. Fairchild, Greenwald, and Decker (1967), in an evaluation of the indirect haemagglutination as a test for toxoplasmosis, noted a similar discrepancy between the antibody titres in the dye and indirect haemagglutination tests in the early stages of glandular toxoplasmosis. These differences can also be shown in the early stages of accidental laboratory infections (Kayhoe, Jacobs, Beye, and McCullough, 1957; Frenkel, Weber, and Lunde, 1960). Even negative HA results have been reported on rare occasions in the presence of a high dye test titres (Jacobs and Lunde, 1957; Fairchild et al, 1967; Miller and Brown, 1969; Karim and Ludlam, 1973). Thorburn and Williams (1972) and Tönder et al (1974) seem to regard a positive indirect haemagglutination test as due mainly to IgM antibody. However, as we have found high HA titres in old cases (tables II and III) when IgM antibody was not to be expected (and indeed when cell-wall IgM was virtually absent), and, as high titre HA antibody can be found not only in the mother but also in her uninfected infant (to be published), it would appear that the IHAT is also a sensitive indicator of IgG antibody.

The absence of HA antigen on the cell surface of the toxoplasma and its location in the cytoplasm may partly explain the observed sequence of antibody production in toxoplasmosis.

Antibody tests in ocular toxoplasmosis (table II) normally showed an IHAT titre equal to or greater than cell-wall antibody and an IgM titre low or negative even in the acute episodes, findings resembling those in patients recovered from glandular toxoplasmosis (table III). This supports the idea that ocular toxoplasmosis in adults is not normally a new infection (Jacobs, Cook, and Wilder, 1954;
Frenkel and Jacobs, 1958). In eye infections theté appears to be no case for a combination of tes and a single test either for IHA or cell-wall antibody should be sufficient.

In considering the relative merits of these tes the most useful for routine purposes are th ones measuring cell-wall antibody, since this develoas at an earlier stage in the disease and to a higher titre. There is the choice of the dye, complemen $P$ fixation, direct agglutination, and immunofluo $\overrightarrow{\omega_{*}}$ escent antibody tests.

The dye test has its well known defects, but $\frac{\sqrt{68}}{8}$ reliable in experienced hands and has the support of many years of use. However, the complemento fixation, direct agglutination, and $\mathrm{IgG} / \mathrm{IgM} \overrightarrow{\mathrm{M}}$ immunofluorescent antibody tests have the advañ tage that the antigen can be stored and if necessary provided from a central source. The complementfixation test used, essentially that of Fulton and Fulton (1965), differs from many used in the pa; in that it consists of whole parasites and tests for cell-wall antibody rather than of an antigen conct sisting solely or largely of soluble antigen. It is of test that could be readily carried out in laboratories where viral complement-fixation tests are dom routinely by microtitre techniques. The diree agglutination test has the merit of great simplicit but the requirements for antigenic purity are mo demanding and the greater quantity of antigem needed may be a practical problem. The IgG/IgN $\vec{E}$ immunofluorescent antibody test is useful when not many tests are carried out and when there is alread the experience and equipment for this type technique. The choice of method will therefore vary from laboratory to laboratory.

When a high borderline titre is obtained with on. of these tests it may be useful to perform the indireg haemagglutination and/or IgM-immunofiuoresce

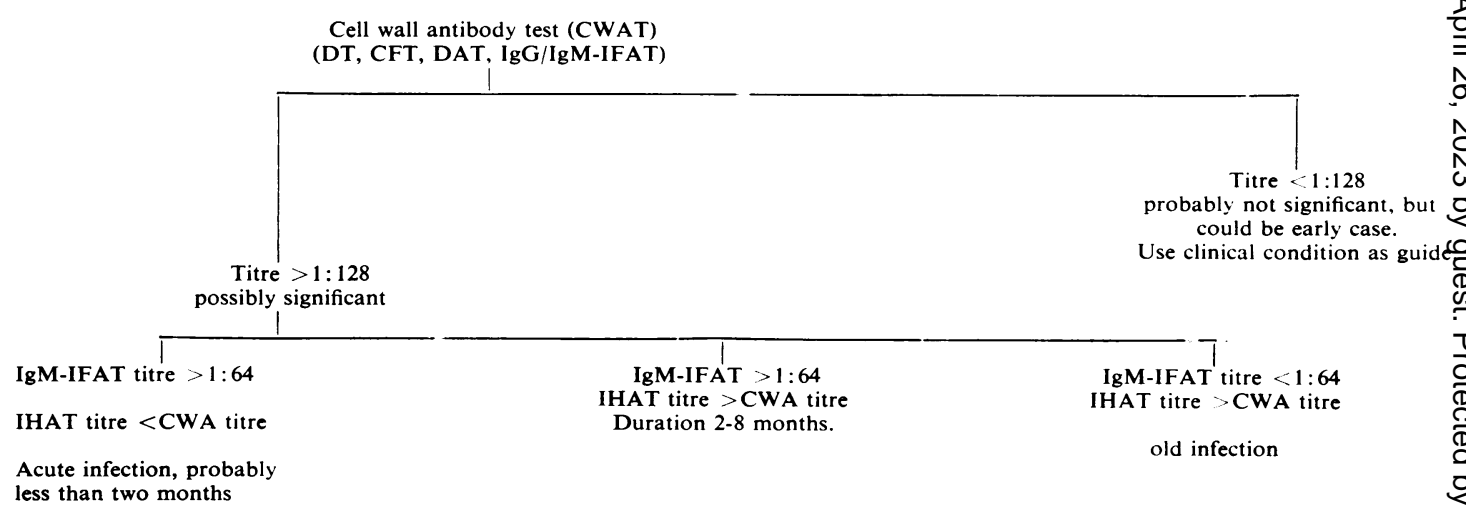

Fig 3 Scheme for determining the stage of disease in toxoplasmosis by different serological tests on a single serum. 
antibody tests to determine whether the cell-wall antibody level is due to a current, recently past, or old infection. For example, where the cell-wall antibody titre is borderline, eg, $1: 256$, a positive IgM titre of, eg, 1:128, would suggest an early or current infection, a negative IgM test a past infection, unrelated to the patient's current condition. A low indirect haemagglutination test titre would suggest an early infection, a high titre one of longer duration. Figure 3 summarizes the use and interpretation of the tests. The titres mentioned are rather arbitrary, but have proved useful in this laboratory and of course the clinical condition must often influence the choice of tests and the interpretation of the results.

We believe that the methods described here and the interpretation of the results of tests carried out on single sera will provide useful information regarding the stage and duration of infection in toxoplasmosis and will therefore be of value in the diagnosis of the disease.

We wish to thank Professor G. Gowland for his advice and support in carrying out this investigation.

\section{References}

Beattie, C. P. (1957). Clinical and epedemilogical aspects of Toxoplasmosis. Trans. roy. Soc. Trop. Med. and Hyg. 51, 96-103.

Beverley, J. K. A., and Beattie, C. P. (1952). Standardization of the dye test for toxoplasmosis. J. clin. Path., 5, 350-353.

Bradstreet, C. M. P., and Taylor, C. E. D. (1962). Technique of complement-fixation test applicable to the diagnosis of virus diseases. Mth. Bull. Minist. Hlth, 21, 96-104.

Chessum, B. S. (1970). Examination of sera for toxoplasmosis antibody using immunofluorescence. J. med. Lab. Technol., 27, 49-54.

Chordi, A., Walls, K. W., and Kagan, I. G. (1964). Studies on the specificity of the indirect haemagglutination test for toxoplasmosis. J. Immunol., 93, 1024-1033.

Couzineau, P., and Baufine-Ducroq, H. (1970). Agglutination directe des toxoplasmes. Ann. Biol. clin., 28, 411-415.

Dropsy, G., Carquin, J., and Croix, J.-C. (1971). Techniques de mise en evidence des anticorps de type IgM dans les infections congénitales. Ann. Biol. clin., 29, 67-73.

Fairchild, G. A., Greenwald, P., and Decker, H. A. (1967). An evaluation of the indirect haemagglutination test for toxoplasmosis. Amer. J. trop. Med. Hyg., 16, 278-283.

Feldman, H. A., and Miller, L. T. (1956). Serological study of toxoplasmosis prevalence. Amer. J. Hyg., 64, 320-335.

Fleck, D. G. (1961). Serological tests for toxoplasmosis. Nature (Lond.), 190, 1018-1019.

Fletcher, S. (1965). Indirect fluorescent antibody technique in the serology of Toxoplasma gondii. J. clin. Path., 18, 193-199.

Frenkel, J. K., and Jacobs, L. (1958). Ocular toxoplasmosis, pathogenises, ciagnosis, and treatment. Amer. med. Ass. Arch. Ophthal., 59, 260-279.

Frenkel, J. K., Weber, R. W., and Lunde, M. N. (1960). Acute toxoplasmosis. J. Amer. med. Ass., 173, 1471-1476.
Fulton, J. D., and Fulton, F. (1965). Complement fixation tests in toxoplasmosis with purified antigen. Nature (Lond.), 205, 776778.

Fulton, J. D., and Turk, J. L. (1959). A direct agglutination test for Toxoplasma gondii. Lancet, 2, 1068-1069.

Goldman, M. (1957). Staining Toxoplasma gondii with fluoresceinlabelled antibody. II. A new serological test for antobodies to toxoplasma based upon inhibition of specific staining. J. exp. Med., 105, 557-573.

Jacobs, L., Cook, M. K., and Wilder, H. C. (1954). Serologic data on adults with histologically diagnosed toxoplasmic chorioretinitis. Trans. Amer. Acad. Ophthal., 58, 193-200.

Jacobs, L., and Lunde, M. N. (1957). A haemagglutination test for toxoplasmosis. J. Parasit., 43, 308-314.

Jennis, F. (1966). A simplified haemagglutination test for toxoplasmosis using pyruvic aldehyde treated cells. Aust.J. exp. Biol. med. Sci., 44, 317-322.

Karim, K. A., and Ludlam, G. B. (1973). Haemagglutination test for toxoplasmosis. (Letter) J. clin. Path., 26, 162.

Kayhoe, D. E., Jacobs, L., Beye, H. K., and McCullough, N. B. (1957). Acquired toxoplasmosis: observations on two parasitologically proved cases treated with pyrimethamine and triple sulphonamides. New Engl. J. Med., 257, 1247-1254.

Kelen, A. E., Ayllon-Leindl, L., and Labzoffsky, N. A. (1962) Indirect fluorescent antibody method in serodiagnosis of toxoplasmosis. Canad. J. Microbiol., 8, 545-554.

Knierim, F., Niedmann, G., and Thiermann, E. (1960). La reacción de hemaglutinacion aplicada al diagnóstico serológico de la toxoplasmosis. Biol. Chil. Parasit., 15, 48-50.

Lewis, W. P., and Kessel, J. F. (1961). Hemagglutination in the diagnosis of toxoplasmosis and amebiasis. Arch. Ophthal. $66,471-476$

Lunde, M. N., and Jacobs, L. (1967). Differences in toxoplasma dye test and hemagglutination antibodies shown by antigen fractionation. Amer. J. trop. Med. Hyg., 16, 26-30.

Miller, L. H., and Brown, H. W. (1969). The serologic diagnosis of parasitic infections in medical practice. Ann. intern. Med. 71, 983-992.

Mitchell, R. G., and Green, C. A. (1960). The haemagglutination test for toxoplasma antibodies. J. clin. Path., 13, 331-335.

Remington, J. S., Miller, M. J., and Brownlee, I. (1968). IgM antibodies in acute toxoplasmosis. II. Prevalence and significance in acquired cases. J. Lab. clin. Med., 71, 855-866.

Sabin, A. B. (1949). Complement fixation test in toxoplasmosis and persistence of the antibody in human beings. Pediatrics, 4, 443-453.

Sabin, A. B., and Feldman, H. A. (1948). Dyes as microchemical indicators of a new immunity phenomenon affecting a protozoon parasite (Toxoplasma). Science, 108, 660-663.

Steen, E., and Kåss, E. (1951). A new toxoplasma antigen for complement fixation test. Acta. path. microbiol. scand., 28, 36-39.

Thalhammer, O. (1956). Uber ein neues, haltbares Antigen für KBR und Hauttest auf Toxoplasmose. Mschr. Kinderheilk. 104, 110-112.

Thiermann, E., and Stagno, S. (1971). Demonstración de anticuerpos IgM en casos de toxoplasmosis aguda y crónica. Bol. Chil. Parasit., 26, 55-56.

Thörburn, H., and Williams, H. (1972). A stable haemagglutinating antigen for detecting toxoplasma antibodies. J. clin. Path., 25, $762-767$.

Tönder, O., Closs, O., and Digranes, A. (1974). Comparison of the Indirect Haemagglutination and Dye Test for Detection of Antibodies to Toxoplasma gondii. Scand. J. infect. Dis., 6, 63-68.

Warren, J., and Russ, S. B. (1948). Cultivation of Toxoplasma in embryonated egg: an antigen derived from chorioallantoic membrane. Proc. Soc. exp. Biol. (N.Y.), 67, 85-89.

World Health Organization (1969). Toxoplasmosis. WHO Techn. Rep. Ser., 431, 18-19. HMSO, London. 